\title{
The Effect of Social Media on Introverted Behavior and the Quality of Interpersonal Communication of Students in Primary Schools
}

\author{
$1^{\text {st }}$ Kharisma Reza Adrianto \\ Primary Teacher Education \\ Department, Faculty of Humanities, \\ Bina Nusantara University \\ Jakarta, Indonesia
}

\author{
$2^{\text {nd }}$ Freddy Widya Ariesta \\ Primary Teacher Education \\ Department, Faculty of Humanities, \\ Bina Nusantara University \\ Jakarta, Indonesia \\ freddy.ariesta@binus.ac.id
}

\begin{abstract}
This study aims to determine the effect of social media on introverted behavior and the quality of interpersonal communication in students in primary schools. The population in this study were 143 respondents from 5 different schools in West Jakarta and East Jakarta. This research uses the Retrospective research method or the Ex Post Facto research method. The sampling technique uses Purpose Sampling. Data collection techniques using questionnaires and interview methods. The quantitative statistical analysis technique used is the Pearson correlation test using SPSS version 23. From the results of this study, the significance value of 0.00 is less than 0.05 and the value of $t$ arithmetic is 4.98 greater than the value of $t$ table of 2.07, then it is concluded that $\mathrm{H} 1$ and $\mathrm{H} 2$ are accepted, meaning there is an influence of social media on introvert behavior and Quality Interpersonal Communication in Primary School students in Jakarta.
\end{abstract}

Keywords-Social Media, Introvert, Interpernonal, Primary Schools

\section{INTRODUCTION}

Developments in the current era of globalization in the 21 st century one of which is to be marked by advances in technology, particularly in the field of communication and information. The development of information technology brings a change in society in general [1][2]. Digital community information will be identified with the number of media that is consumed [2]. This can also be proven by the very rapid circulation of information around them. Besides, media information is not only made by certain institution media, but all people can also produce and publish information [3].

Over time, the development of the function and purpose of technology is not only intended for commercial and educational purposes only but developed further for the communication functions that can be called with social media [4]. At present, the presence of digital information media is being used as a social media community [5]. Because with social media the public can freely share information and communicate with many people without the need to think about distance and time. Social media attract anyone interested to participate by giving feedback openly, comment, and share information in a short time and unlimited [6]. Social media remove restrictions on socializing because in social media there is no limitation of space and time, one can communicate whenever, wherever located [7].

Social media in general is included in the technological development of the advanced category. Social media can allow each user to be able to communicate, share information to achieve certain goals [8]. However, on the other hand, social media has a negative impact on its users. The birth of social media has led to a shift in people's behavior patterns both in terms of culture, ethics, and norms [9][10]. Various communication technologies are created to make human life becomes easy and convenient, but such devices are used by people with different motivations and goals that cause unwanted adverse effects [11]. As reported from the online media that Japan's Ministry of Education estimates that about 518,000 children in 2015 in Japan at the age of 12-18 years are addicted to the internet and they should be rehabilitated, as the Japanese government was worried if there is an impact on the psychological and emotional [12][13]. Based on data from the Children's Media Development, it is stated that children of Primary School age in Indonesia watch television around 6-8 hours a day [14]. In fact, because of the many social media used by children can affect their behavior in the relationship and communication with parents, school friends, playmates, and other people around [14][15]. The ease with which new communication technology makes it dependent. Dependency Theory defines that dependence is related to efforts to meet the needs or achievement of goals by relying on other resources in this case social media [16][17]. Its existence is considered a dominant social force. As Neil Postman stated, that technology encourages 
"technopoly culture", which is a culture in which the community in it deifies technology and technology controls all aspects of life [18][19].

Based on the survey of Indonesian Internet Service Provider Association penetration of Internet users in Indonesia the most are those who have 13-18 years of age in the amount of $75.50 \%$ have used the Internet, which means that the majority of internet users in Indonesia are children of school-age [20].

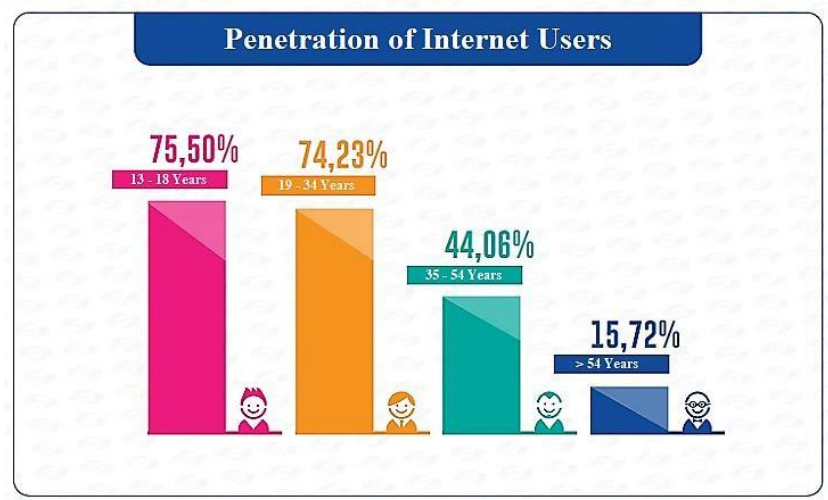

Fig. 1. Penetration of Internet Users Based on Age in Indonesia

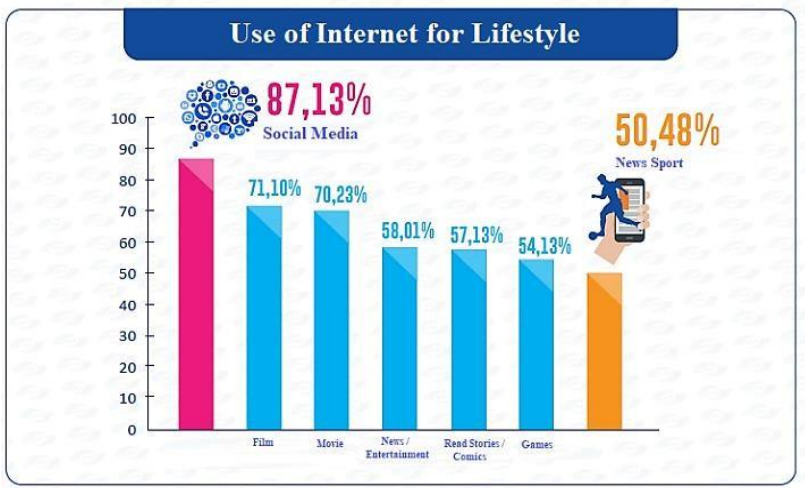

Fig. 2. Use of Internet Lifestyle Sector in Indonesia

Based on the survey of the Indonesian Internet Service Provider Association in Figure 2. Whereas the field of lifestyle Internet use in Indonesia which most is used for social media, meaning most oaring in Indonesia using the Internet for social media activities [20].

Theresa Orange and Louise O'Flynn in The Media Diet for Kids mention that some behavior is obtained from the use of TV among other anti-social behavior, apathy, child sex knowing vaguely, early adulthood, and the occurrence of energy imbalance [21]. Changes in individual behavior towards the use of social media will impact especially in the conduct of daily communication. Changes in human behavior can't be separated from the individual's own (internal factors) and the environment in which individuals live (external factors) [22]. Individual behavior can affect the individual itself, besides that the behavior also affects the environment, and likewise the environment can affect individuals [22]. One of the effects of social media for elementary and middle school children and adolescents is to shape their behavior to be closed to others. Behavior covered a person's response to the stimulus in the form enclosed. This behavior will tend to close themselves off from their social environment and difficult to hang out and socialize with their peers in the neighborhood [23].

In addition to behavior in children Primary School age affected will be social media, other things emerge from social media is a result of interpersonal communication skills. Interpersonal communication is a communication made with others and is a method of communication that is often used by humans when working, socializing, and socializing [24][25]. Lack of communication skills is a fairly serious problem that is often faced by all individuals. Without two-way communication, then the whole of society will have difficulty in socializing. Social media has given a wide impact on the ability to communicate, especially children of primary school students. They tend to be fonder of communicating indirectly, through short messages on mobile phones and use other social media to communicate [26]. This will certainly have an impact on children's skills at primary school age when they communicate directly with their interlocutors.

When individuals experiencing difficulties in its development, to overcome this use of the Internet becomes more important than what other people do in general because online activities to broaden and strengthen their social network [27]. However, this kind of activity can be dangerous if social media is the main focus of their lives as a means to obtain social support and interpersonal relationships. Inhibition can also inhibit the ability to communicate student achievement, students who had difficulty in communicating, and are not able to socialize and adapt to their peers and surroundings [24][28][29].

The whole technological developments that have occurred in the current era, either indirectly or directly to a major impact on the social life of a community and can have an impact on the people

directly involved in the technology development cycle is going on at this time, especially in children at primary school age. The impact that will result from the technology development cycle time could

have an impact on behavior change and change communication style at the same time. The purpose of this study was to see how much influence social media has on introverted behavior change and the quality of interpersonal communication towards Primary School students.

\section{LITERATURE REVIEW}

\section{A. Social Media}

Social Media is an online media, the users can easily participate, share, and create content including blogs, social networks, wikis, forums, and virtual worlds [30]. Social media is a social network in the internet world, which have relationships and connect with other individuals.

Internet is growing forward and this time emerged a social media that can expand the network of friends for each user. social media as a means of information dissemination and social interaction

is an effective tool for information that can be found quickly and interaction is not limited only to individuals but also to groups [30][31]. Social media at this time as a 
community event to socialize online with other people without having to meet in person [31].

Classification of social media can be divided into six parts: (1) Collaborative Project, (2) Blogs (3) Content Community, (4) Virtual Game Worlds, (5) Virtual Social Worlds, (6) Social Networking Sites [31]. Based on the six classifications of social media, that will be emphasized is the social networking site, which is where in this aspect the researchers wanted to see how far the impact of social media. This social media such as Instagram, Facebook, YouTube, and others who have the same features. The development of social media certainly has many impacts, both positive and negative impacts for its users, especially in pre-teen age. The ease with which new communication technology makes it dependent [16][17].

\section{B. Introvert Behaviour}

Behavior is an action or behavior of an organism that can be observed and can even be studied. The behavior of an individual's response to a stimulus or an action that can be observed and has a specific frequency, duration, and purpose, either consciously or unconsciously [32]. Human behavior is formed because of a need and condition [32][33].

Introverted behavior is a trait and character that tends to be solitary. They are closed personalities and exclude social life from orientation into oneself, ie people who tend to withdraw from social contact [33]. characteristics of introverted behavior in a person, are: (1) Prefer to cover up feelings, (2) Do not use too much physical activity, (3) Prefer only a few special friends, (4) Do not like to take risks [33]. Someone has an introverted personality as explained above, then that person will limit his daily activities, starting from his daily routine, talking with others to avoid enough activities that involve excessive physical and energy [33][34].

\section{Interpersonal Communication}

Interpersonal communication is defined as communication Face to Face at the same time giving and receiving of information carried by two persons or more, both verbal and non-verbal content of the message can respond directly [35]. Interpersonal communication is very potential to influence or persuade others because it can use the five senses tools to enhance message persuasiveness that we do not communicate or between individuals who are communicating [32][35]. Interpersonal communication can be divided into two types: (1) dyadic communication, (2) Small group communication [24][25]. Factors that can influence the level of interpersonal relationships are (1) Tolerance, (2) Openness, (3) Trust [36]. In simple, a process can be described as a process of communication that connects the sender to the receiver of the message [25]. Interpersonal communication is an Action-Oriented, is an action-oriented in a particular destination. The purpose of interpersonal communication is (1) Expressing attention to others, (2) Finding Yourself, (3) Finding Pleasure or Time-Spending, (4) Eliminating Losses Due to Incorrect Communication. developments in social media can affect the behavior and the quality of communication on any users, particularly at primary school age, ie from age 8 to 13 years [24][25].

\section{METHODS}

A. Design Research

Researchers will choose the Ex Post Facto research model of Causal Comparative Research because the research model (case-control) has some of the criteria that are following the study design that was made by previous researchers. Ex Post Facto research or what can be called a retrospective is a study in which the independent variables occur when researchers begin with this research.

\section{B. Subject Research}

The population is the generalization which consists of an object or subject that has certain qualities and characteristics defined by the researchers to learn and then be deduced [37]. The researcher uses the Purpose Sampling technique because the sampling has been planned and has determined the respondents. The subjects were 143 students in grade 6 Primary School consists of five schools in the city of Jakarta, West Jakarta, and East Jakarta.

\section{Data Collection Instruments}

Researchers used questionnaires to retrieve data related to the influence of social media on introverted behavior and the quality of communication in grade 6 Primary School students. In the questionnaire sheet is divided into two, is introverted behavior questionnaire sheet consisting of three aspects; (1) Physical activity, (2) Liking Some Friend Specials Only, (3) Many Think Before Acting or Before Speaking, and sheet questionnaire interpersonal communication consists of three aspects of the research: (1) Source and Receiver difficult to be identified, (2 ) the same position in the communication process, (3) involved in the ongoing communication process. Researchers are also using evaluation test instruments in the form of questions in the pretest and posttest to measure student learning outcomes. In the research data collection techniques, researchers used multiple techniques and procedures tailored to the characteristics of the data. Data collection techniques were carried out by interviewing, documenting, observing, and evaluating tests using the instrument lattice that had been developed and developed.

\section{Data Analysis}

Data analysis techniques of social media influence on the behavior of introverted and interpersonal communication quality using a quantitative statistical test. The research statistical test used is the Pearson correlation test [37]. This correlation test was used researchers to determine whether there is a relationship between the dependent variable with the independent variable if the significance value $<0.05$ then correlated and if the significance value $>0.05$ then uncorrelated.

\section{RESULTS AND DISCUSSION}

Learning activities or processes are always related to learning objectives, as well as learning planning and implementation. By planning and implementing good learning, it will create effective learning [38]. The data to be analyzed is the result of data from questionnaires and interviews with Primary School students. The study was conducted at five different schools, three of the schools in East Jakarta and two schools in West Jakarta. The five 
schools are Bambu Apus 01 Primary Schools, 02 Primary Schools and 03 Pondok Rangoon, 01 Primary Schools Tanjung Duren Selatan, and the last one in the Primary School 03 Tomang.

\section{A. Analysis of the Effect of Social Media on Introverted Behavior}

In this introvert behavior analysis, data were obtained from a questionnaire that had been distributed to respondents.

\begin{tabular}{|c|c|c|}
\hline & introvert behavior & social media \\
\hline \multirow{3}{*}{$\begin{array}{r}\text { introvert behavior Pearson Correlation } \\
\text { Sig. (2-tailed) N }\end{array}$} & 1 & $.932^{* * *}$ \\
\hline & & .000 \\
\hline & 30 & 30 \\
\hline \multirow{3}{*}{$\begin{array}{l}\text { Pearson Correlation } \\
\text { Sig. (2-tailed) N }\end{array}$} & $.932^{* *}$ & 1 \\
\hline & .000 & \\
\hline & 30 & 30 \\
\hline
\end{tabular}

Based on the data in table I, it shows that the correlation test results above using the SPSS program obtained a significance value of 0,000 for introverted behavior variables, and a significance value of 0.000 for social media variables was obtained. Of the two variables that both received a significance value of $0.000<0.05$, it can be said that the two variables are correlated and are positive. Then the calculated r-value on social media variables and introverted behavior obtained a value of 0.932 .

TABLE II. RESULTS OF SOCIAL MEDIA CORRELATION TESTS IN INTERPERSONAL COMMUNICATION

Interpersonal Communication

\begin{tabular}{|c|c|c|}
\hline & interpersonal communication & social media \\
\hline \multirow{3}{*}{$\begin{array}{l}\text { interpersonal communication Pearson Correlation } \\
\text { Sig. (2-tailed) N }\end{array}$} & 1 & $.530^{* *}$ \\
\hline & & .004 \\
\hline & 28 & 28 \\
\hline \multirow[t]{3}{*}{ social media } & $.530^{* * *}$ & 1 \\
\hline & .004 & \\
\hline & 28 & 28 \\
\hline
\end{tabular}

Based on the data in table II, it shows that the correlation test results above using the SPSS program obtained a significance value of 0.004 for introverted behavior variables, and a significance value of 0.004 for social media variables was obtained. Of the two variables, both obtain significance values of $0.004<0.05$ it can be said that the two variables are correlated and are positive. Then the calculated r-value on social media variables and introverted behavior obtained a value of 0.530 . meaning that these two variables have a fairly strong relationship. This is based on the table of correlation and strength of relationships.

\section{CONCLUSIONS}

Based on the results of research and discussions that have been made, the following conclusions are obtained: (1) There is an influence from social media on introverted behavior in Primary School students in SDN 01 Tanjung Duren. This is based on the results of a simple linear regression analysis test, obtained a significance value of 0,000 and it is known that the significance value is less than 0.05 (2) There is an influence of social media on

\section{B. Analysis of the Effect of Social Media on}

In this analysis of interpersonal communication, data were obtained from questionnaires that had been distributed to respondents. In this interpersonal communication analysis, the researcher will conduct a normality test first then after that do a linearity test for a simple linear regression test, a correlation test, and finally a hypothesis test. Next is the elaboration of the recapitulation data of Pearson correlation test calculations.

interpersonal communication in Primary School students at SDN 03 Pondok Ranggon, East Jakarta. This is based on the results of the simple linear regression analysis test, obtained a significance value of 0.004 and it is known that the significance value is less than 0.05

So social media currently influences the formation of students' introverted behavior and the quality of interpersonal communication. This is following relevant research that Facebook social media also influences Primary School students [39]. This social media effect can affect something personally in Primary School students [39]. Social media is divided into 2 effects namely negative and positive effects on children's social change. The negative impact arising from social media on children is that they tend to be anti-social because they are too absorbed in social media compared to face to face with the real world. [2][6][10].

Furthermore, there are several recommendations made by researchers related to this research, namely the role of a teacher during class, to always provide an oral and direct understanding of the positive and negative impacts of social media that they access every day. This is intended 
so that they slowly understand and realize the impact of social media they access every day. The role of parents at home is very important because students and students have more time at home. Parents must have disciplinary steps in implementing regulation in the home regarding using their children's cell phones.

\section{REFERENCES}

[1] Wijaya, E. Y., Sudjimat, D. A., Nyoto, A., \& Malang, U. N. (2016). Transformasi pendidikan abad 21 sebagai tuntutan pengembangan sumber daya manusia di era global. In Prosiding Seminar Nasional Pendidikan Matematika (Vol. 1, No. 26, pp. 263-278).

[2] Cahyono, A. S. (2016). Pengaruh media sosial terhadap perubahan sosial masyarakat di Indonesia. Jurnal Publiciana, 9(1), 140-157.

[3] Nicholas, D., Huntington, P., Jamali, H. R., Rowlands, I., \& Fieldhouse, M. (2009). Student digital information-seeking behavior in context. Journal of Documentation.

[4] Sherlyanita, A. K., \& Rakhmawati, N. A. (2016). Pengaruh dan pola aktivitas penggunaan internet serta media sosial pada siswa SMPN 52 Surabaya. Journal of Information Systems Engineering and Business Intelligence, 2(1), 17-22.

[5] Kelton, K., Fleischmann, K. R., \& Wallace, W. A. (2008). Trust in digital information. Journal of the American Society for Information Science and Technology, 59(3), 363-374.

[6] Putri, W. S. R., Nurwati, N., \& Budiarti, M. (2016). Pengaruh media sosial terhadap perilaku remaja. Prosiding Penelitian dan Pengabdian kepada Masyarakat, 3(1).

[7] Azizan, H. (2016). Pengaruh kepercayaan diri terhadap ketergantungan media sosial pada siswa di SMK Negeri 1 Bantul. Jurnal Riset Mahasiswa Bimbingan Dan Konseling, 5(6).

[8] Valenzuela, S., Arriagada, A., \& Scherman, A. (2014). Facebook, Twitter, and youth engagement: A quasiexperimental study of social media use and protest behavior using propensity score matching. International Journal of Communication, 8, 25.

[9] Patton, D. U., Hong, J. S., Ranney, M., Patel, S., Kelley, C., Eschmann, R., \& Washington, T. (2014). Social media as a vector for youth violence: A review of the literature. Computers in Human Behavior, 35, 548-553.

[10] Soliha, S. F. (2015). Tingkat ketergantungan pengguna media sosial dan kecemasan sosial. Interaksi: Jurnal Ilmu Komunikasi, 4(1), 1-10.

[11] Kaya, T., \& Bicen, H. (2016). The effects of social media on students' behaviors; Facebook as a case study. Computers in Human Behavior, 59, 374-379.

[12] Hasegawa, K., Shinohara, C., \& Broadbent, J. P. (2007). The effects of "social expectation on the development of civil society in Japan. Journal of Civil Society, 3(2), 179-203.

[13] Takahashi, T. (2014). Youth, social media, and connectivity in Japan. In the Language of Social

[14] Media (pp. 186-207). Palgrave Macmillan, London.

[15] Efendi, A., Astuti, P. I., \& Rahayu, N. T. (2017). Analisis pengaruh penggunaan media baru terhadap pola interaksi sosial anak di Kabupaten Sukoharjo. Jurnal Penelitian Humaniora, 18(2), 12-24.

[16] Chusna, P. A. (2017). Pengaruh media gadget pada perkembangan karakter anak. Dinamika Penelitian: Media Komunikasi Penelitian Sosial Keagamaan, 17(2), 315-330.

[17] Soliha, S. F. (2015). Tingkat ketergantungan pengguna media sosial dan kecemasan sosial. Interaksi: Jurnal Ilmu Komunikasi, 4(1), 1-10.

[18] Schrock, A. (2006). Myspace or our space: A media system dependency view of myspace.

[19] Postman, N. (2000, June). The humanism of media ecology. In Proceedings of the Media Ecology Association (Vol. 1, No. 1, pp. 10-16).

[20] Straubhaar, J., LaRose, R., \& Davenport, L. (2013). Media now: Understanding media, culture, and technology. Cengage Learning.

[21] APJII, P. (2017). Perilaku Pengguna Internet Indonesia. Asosiasi Penyelenggara Jasa Internet Indonesia, Survei.

[22] Orange, T. (2005). The media diet for kids. Penerbit Serambi.
[23] Ariesta, F. W., Setyowati, D. L., \& Purwanti, E. (2017) Pengembangan Model Spot Capturing Problem untuk Membangun Karakter Siswa Sekolah Dasar. Jurnal Inovasi Pendidikan Dasar, 3(1), 1-8.

[24] Simanjuntak, V. P. C. (2018). Intensitas Penggunaan Media Sosial Terhadap Perilaku Komunikasi pada Mahasiswa Kepribadian Introvert (Studi Kuantitatif Mengenai Intensitas Penggunaan Media Sosial Instagram Terhadap Perilaku Komunikasi pada Mahasiswa Kepribadian Introvert di Universitas Sumatera Utara).

[25] Aw, S. (2011). Komunikasi interpersonal. [25] Aw, S. (2011). Komunikasi Antarpribadi.

[26] Pratiwi, N., \& Pritanova, N. (2017). Pengaruh literasi digital terhadap psikologis anak dan remaja. Semantik, 6(1), 11-24.

[27] Šmahel, D., \& Blinka, L. (2012). Excessive internet use among European children. Children, risk, and safety on the internet: Research and policy challenges in comparative perspective191,

[28] FAINZAH, V. N. (2016). Upaya Meningkatkan Kecerdasan Interpersonal Siswa Kelas Iv Sd 3 Sidigede Pada Pembelajaran Ips Melalui Model Numbered Heads Together Dengan Pemanfaatan Lingkungan Sekitar (Doctoral dissertation, Universitas Muria Kudus)

[29] Muniroh, S. M. (2013). Pengembangan Kecerdasan Interpersonal Anak. Jurnal Penelitian, 6(1).

[30] Cahyono, A. S. (2016). Pengaruh media sosial terhadap perubahan sosial masyarakat di Indonesia. Jurnal Publiciana, 9(1), 140-157.

[31] Ferlitasari, R. (2018). Pengaruh Media Sosial Instagram Terhadap Perilaku Keagamaan

[32] Remaja (Studi pada Rohis di SMA Perintis 1 Bandar Lampung) (Doctoral dissertation, UIN Raden Intan Lampung).

[33] Mantasia, M., \& Jaya, H. (2016). Pengembangan teknologi augmented reality sebagai penguatan dan penunjang metode pembelajaran di SMK untuk implementasi Kurikulum 2013.

[34] Jurnal Pendidikan Vokasi, 6(3), 281-291.

[35] Priharta, I. G. M. Y., Dharsana, I. K., \& Suarni, N. K. (2019, July). The Effectiveness of Behavioralconservation with Modeling Techniques Through Lesson Study to Improve Character of Fun for Others. In International Conference on Technology and Educational Science (pp. 30-35). Redwhite Press.

[36] Rosida, E. R., \& Astuti, T. P. (2015). Perbedaan penerimaan teman sebaya ditinjau dari tipe kepribadian ekstrovert dan introvert. Empati, 4(1), 77-81.

[37] Herawati, N., \& Astuti, T. P. (2015). Pengaruh Pelatihan Asertivitas Terhadap Komunikasi

[38] Interpersonal Siswa: Studi Eksperimental pada Siswa Kelas VIII. Empati, 4(1), 130-133.

[39] Yusuf, A. M. (2017). Pengaruh Komunikasi Interrpersonal Guru Terhadap Prestasi Belajar

[40] Siswa Sekolah Menengah Kejuruan (SMK) Negeri 7 Makassar (Doctoral dissertation, UIN Alauddin Makassar).

[41] Sugiyono, P. D. (2017). Metode Penelitian Bisnis: Pendekatan Kuantitatif, Kualitatif,

[42] Kombinasi, dan R\&D. Penerbit CV. Alfabeta: Bandung.

[43] Siregar, S. (2013). Statistik parametrik untuk penelitian kuantitatif. Jakarta: Bumi Aksara, 102. [ Kasim, F. (2016). Efek Media Sosial (FACEBOOK) Terhadap Murid Kelas VI (Enam) SDN

[44] Bontokamase Sungguminasa (Doctoral dissertation, Universitas Islam Negeri Alauddin Makassar). 